Research Article

\title{
Utilization of Synthesized Zeolite for Improved Properties of Pyrolytic Oil Derived from Used Tire
}

\author{
Julius I. Osayi (iD and Peter Osifo \\ Department of Chemical Engineering, Vaal University of Technology, Vanderbijlpark, South Africa \\ Correspondence should be addressed to Julius I. Osayi; ojgrants@yahoo.com
}

Received 6 November 2018; Revised 27 February 2019; Accepted 7 April 2019; Published 2 May 2019

Academic Editor: Jose C. Merchuk

Copyright (C) 2019 Julius I. Osayi and Peter Osifo. This is an open access article distributed under the Creative Commons Attribution License, which permits unrestricted use, distribution, and reproduction in any medium, provided the original work is properly cited.

\begin{abstract}
This paper reports the investigation of zeolite $\mathrm{NaY}$ synthesized from kaolin, a locally abundant soil material found in the Benin City metropolis, Nigeria, as a suitable catalyst and its effect on the properties of pyrolytic oil produced from used tires. The pyrolysis process was conducted from a range of 1 to $10 \mathrm{wt} . \%$ of catalyst concentration to the used tire at an operating temperature of $600^{\circ} \mathrm{C}$, heating rate of $15^{\circ} \mathrm{C} / \mathrm{min}$, and particle size of $6 \mathrm{~mm}$. An increase in the catalyst weight gave a maximum yield of catalytic pyrolytic oil (CPO) of $21.3 \mathrm{wt} . \%$ at a catalyst-to-tire ratio of $7.5 \mathrm{wt} . \%$. Although this was lower than the noncatalyzed pyrolytic oil yield (34.40 wt.\%), the quality in terms of chemical composition and hydrocarbon fuel range varied from that of the noncatalyzed pyrolytic oil, as indicated by the FT-IR, NMR, and GC-MS analyses. From the GC-MS result, the $\mathrm{CPO}$ gave a benzene yield higher than that of noncatalyzed pyrolytic oil. The CPO benzene yield can be ranked as CPO $(5 \mathrm{wt} . \%)>\mathrm{CPO}(1 \mathrm{wt} . \%)>\mathrm{CPO}(10 \mathrm{wt} . \%)>\mathrm{CPO}(7.5 \mathrm{wt} . \%)>$ noncatalyzed pyrolytic oil. The catalyst also improved the yield of other valuable chemicals such as ethylbenzene, $o$ - and $p$-xylene, styrene, toluene, quinoline, pyrene, thiophene, P-cresol, phenol, and limonene in the pyrolytic oil. For hydrocarbon range, the catalyst displayed the potential to increase the yield of carbon range (C6-C15), which is similar to gasoline (C6-C12) and kerosene (C11-C14), with a lower yield of diesel and fuel oils (C11-C20) when compared to the noncatalyzed pyrolytic oil.
\end{abstract}

\section{Introduction}

Used tires, as an environmental nuisance and threat to land mass availability, are no longer disputed amongst the nations of the world as it has been identified as one of the difficult problems that must be addressed [1-3]. According to literature, an estimated amount of over one billion used tires are produced annually [4]. Unlike other organic solid waste, its major challenge lies in its disposal management. This is due to the nonbiodegradable configuration of used tires arising from the tough physicochemical and structural properties during production to enable it serve its purpose $[3,5,7]$. On the contrary, there is a global energy crisis evident in crude oil price uncertainty and decline in fossil fuel reserves amidst the rising energy demand.

Hence, it is needful to explore available technology to convert materials such as used tires, which is on the increase because of continuous automobile demand, as an alternative source of energy. Amongst several viable technologies available for efficient tire waste management is the pyrolysis process $[8,9]$. Pyrolysis does not only serve as an energy recovery route for used tires but also the process conditions can be optimized to favor the fraction of interest and obtain other high-value products (Qunhui Lin., Guanyi Chen., 2012). The three basic products obtainable from the pyrolysis process include liquid fraction (pyrolytic oil), solid residue (char), and gases [3, 10-12]. Reports abound in the literature on the suitability of pyrolysis as a thermochemical method could be manipulated to achieve different objectives in used tires recycling $[13,14]$.

An example of such process condition parameter entails the application of catalyst during pyrolysis, which could practically influence the yield and quality of the pyrolysis product particularly the liquid fraction $[12,15]$. This is 
because the liquid fraction possesses not only high calorific value $(\sim 43 \mathrm{MJ} / \mathrm{kg})$ that enables it serve as an alternative fuel or petroleum refinery feedstock but also chemical species (e.g., benzene, toluene, xylenes, and limonene) whose industrial relevance has been reported $[13,16]$. Several research reports have recommended further improvement on the pyrolytic oil to improve its gasoline properties, which has led to increased studies in the use of various catalysts $[15,17,18]$.

Hence, researchers have investigated the influence of various types of catalyst (synthetic and natural) on used tires pyrolysis with study results revealing an improvement in the physicochemical properties and chemical composition of the pyrolytic oil. This is due to the ability of the catalyst to crack higher molecular weight compounds into lighter hydrocarbon products by enhancing the pyrolysis reaction kinetics $[10,19,20]$. The use of catalyst in used tires pyrolysis has enabled the production of more single-ring aromatics such as benzene, toluene, and xylenes, important chemical feedstock for the chemical industry, than the noncatalyzed process. In Olazar et al.'s study [21], HY and H-ZSM-5 zeolite catalyst applied in used tires pyrolysis has confirmed this. Both catalysts significantly decreased the molecular weight of the oil. Also, a high yield of olefins (specifically, ethene and propene), aromatic fractions (more xylenes concentration), and low tar yield was recorded. Subsequently, Shen et al. [22] investigated the influence of USY zeolite catalyst on pyrolysis temperature, heating rate, and products yields of used tires pyrolysis. The outcome revealed that the zeolite USY catalyst leads to a significant decrease in the liquid fraction yield and a resultant increase in gas yield as the catalyst/tyre ratio and pyrolysis temperature increased.

Williams and Brindle [23] investigated the effect of ZSM5 zeolite and two zeolite Y-type catalysts with different $\mathrm{Si} / \mathrm{Al}$ ratios and pore size on the liquid fraction composition and products yields. Their report revealed that zeolite $\mathrm{Y}$ with a lower $\mathrm{Si} / \mathrm{Al}$ ratio gave a significant higher amount of benzene, toluene, xylenes, naphthalene, and alkylated naphthalene than ZSM-5 zeolite catalyst. These could be due to the acidity and larger pore size possessed by the zeolite $\mathrm{Y}$ than the ZSM-5 Zeolite catalyst. Shah et al. [24] have also researched the effect of basic catalysts, magnesium oxides, and calcium carbonate (V) on pyrolysis of used tires. Results showed that both catalysts, $\mathrm{MgO}$ and $\mathrm{CaCO}_{3}$, produced tire pyrolytic oil with fuel properties comparable with fossil diesel. The pyrolytic oil produced from $\mathrm{MgO}$ as a catalyst gave $55 \%$ aromatic hydrocarbons, while $50 \%$ aromatic hydrocarbons were recorded for pyrolytic oil produced from the $\mathrm{CaCO}_{3}$ catalyst. It is noteworthy that catalytic pyrolysis findings are often linked to the structural and chemical properties of the catalyst used $[25,26]$, making room for the possibility of the other catalyst being investigated.

This study aims to investigate the effectiveness of the zeolite NaY catalyst synthesized from kaolin on the physicochemical properties of the pyrolytic oil derived from used tires to attain commercial standard as chemicals and substitute fuel energy source. Kaolin is a cheap and abundant raw material, which researchers have been able to utilize in zeolite catalyst production [27]. Nevertheless, according to literature and knowledge available to the author, no study has focus on the impact of the application of zeolite $\mathrm{NaY}$ obtained using kaolin as a precursor on catalytic pyrolysis of used tires. The liquid oil produced will be characterized using standard techniques such as FT-IR, NMR, and GCMS to determine its fuel suitability and chemical properties for applications in transport and chemical industries.

\section{Materials and Methods}

2.1. Catalysts Preparation and Characterisation. The zeolite $\mathrm{NaY}$ catalyst used in this study was synthesised using kaolin as a precursor for alumina and silica in the laboratory of the School of Chemical and Metallurgical Engineering, University of the Witwatersrand, Johannesburg South Africa. Kaolin clay (referred to as LBK) was collected from Lawani Benin River, a location in Edo State Nigeria. After refining the kaolin and performing the metakaolinization step at $600^{\circ} \mathrm{C}$, the metakaolin produced was then modified to zeolite $\mathrm{NaY}$ via the conventional hydrothermal process based on a previously reported experimental procedure [28]. Table 1 shows the chemical constituents present in the LBK metakaolin produced at $600^{\circ} \mathrm{C}$ revealed by the XRF. Detailed characterisation of the synthesized zeolite $\mathrm{NaY}$ is reported in the literature [29]. Results showed the synthesized zeolite $\mathrm{NaY}$ has remarkable similarity with the referenced commercial zeolite NaY catalyst. The produced catalysts were kept in a desiccator for further use in the study.

\subsection{Details of Experimental Apparatus and Procedure of Catalytic Pyrolysis of Used Tires}

2.2.1. Used Tires Sample Material Preparation and Characterisation. The studied used tires of vehicles were obtained from a selected dumpsite in Johannesburg, South Africa. It was made suitable for analysis and experimental study based on the procedure reported by Osayi et al. [5]. The proximate analysis was done according to ASTM D3172-73 with the PerkinElmer precisely STA6000, Shelton USA simultaneous Analyzer, while the Thermo Scientific Flash 2000 elemental analyzer was used to obtain the elements present in the samples according to ASTM D3176-15. Calorific value of the raw material was found by ASTM E711 using the DryCal modular calorimeter, model 2010, while the thermogravimetric analysis was conducted using an STD-Q600 analyzer from TA instruments.

2.2.2. Catalytic Pyrolysis of Used Tires Experiment. The used tires catalytic pyrolysis experiments were conducted on a lab-scale horizontal fixed-bed reactor experimental setup depicted in Figure 1. The details of the reactor and its operation are available in the literature $[5,6]$.

Unlike the previous study [6], $10 \mathrm{~g} / \mathrm{batch}$ of used tires sample was physically homogenized with catalyst in required ratios ranging from 1 to $10 \%$ by weight loaded on a crucible introduced into the glass quartz tube positioned in the horizontal fixed-bed reactor chamber (for varied catalyst/ 
TABLE 1: XRF chemical constituent present in LBK metakaolin.

\begin{tabular}{lc}
\hline Chemical constituent & Weight (\%) \\
\hline $\mathrm{SiO}_{2}$ & 68.93 \\
$\mathrm{Al}_{2} \mathrm{O}_{3}$ & 24.32 \\
$\mathrm{Na}_{2} \mathrm{O}$ & 0.11 \\
$\mathrm{MgO}$ & 0.24 \\
$\mathrm{Fe}_{2} \mathrm{O}_{3}$ & 0.22 \\
$\mathrm{MnO}$ & 0.02 \\
$\mathrm{CaO}$ & 0.08 \\
$\mathrm{~K}_{2} \mathrm{O}$ & 0.30 \\
$\mathrm{TiO}_{2}$ & 3.09 \\
$\mathrm{P}_{2} \mathrm{O}_{5}$ & 0.10 \\
$\mathrm{Cr}_{2} \mathrm{O}_{3}$ & 0.05 \\
$\mathrm{NiO}$ & 0.0022 \\
$\mathrm{Total}^{\mathrm{LOI}}$ & 99.22 \\
\hline
\end{tabular}

tire ratio runs). Introduction of the sample into the reactor was followed by purging the system with $\mathrm{N}_{2}$ gas at a flow rate of $150 \mathrm{ml} / \mathrm{min}$ for $15 \mathrm{~min}$ to dispel air from the system before commencement of pyrolysis. Then, the heating source of the reactor was switched on, while the set value/operating temperature of $600^{\circ} \mathrm{C}$ at a heating rate of $15^{\circ} \mathrm{C} / \mathrm{min}$ was programmed on the temperature controller. Once the process attained the set temperature, the reactor temperature was kept constant for $30 \mathrm{~min}$, or until no visible flow of liquid was observed before it was cooled down to $20^{\circ} \mathrm{C}$. This will enable all possible liquid and vapour products to exit the reactor to the collection unit. The collection unit comprises of a three-neck round-bottom flask, positioned in a bowl of ice. Both the pyrolytic oil and the gas fraction entered the flask from the reactor outlet via a flexible hose. The ice helped to cool down the condensable fraction of the gas, while the noncondensable gases were collected for analysis (when needed) or allowed to escape through the outlet of the flask connected to the fume hood. On completion of the pyrolysis, $\mathrm{N}_{2}$ gas flow was stopped, and the reactor power was turned off. Upon cooling of the system, the roundbottom flask was disconnected from the reactor, and the pyrolytic oil was collected in a glass vial, weighed, and stored for analyses.

The char left on the sample crucible in the reactor chamber was collected, weighed, and kept in a glass bottle. The weight of the gas was determined by subtracting the sum of the weight of the pyrolytic oil and that of the weight of the char from the initial weight of the feedstock. The experiment was conducted in triplicate for accuracy of data.

2.3. Pyrolytic Product Methods of Analysis. The analyses of catalytic pyrolysis product (pyrolytic oil) obtained under the maximum liquid yield operating conditions were performed in compliance with standard methods and procedures in appropriate instruments. Some physical properties of the pyrolytic oil checked include HHV, density, viscosity, sulphur content, flash point, pour point, refractive index, and $\mathrm{pH}$ value were determined according to the American Society for Testing and Materials (ASTM) standard methods, as shown in Table 2.
FT-IR spectroscopy was used to analyze the functional groups present in the pyrolytic oil. The FT-IR instrument, Bruker Tensor 27 model with Opus software, was used to generate the IR spectra (range of $500-4000 \mathrm{~cm}^{-1}$ ) of the oil. Identification of compounds in the pyrolytic oil was performed using a GC Agilent $\odot$ 7890B and MS Pegasus 4D GC $\times$ GC from Leco. The GC had a capillary configuration

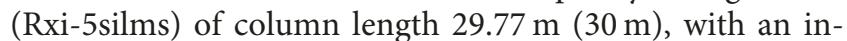
ternal diameter of $250 \mu \mathrm{m}$, with a film thickness of $0.25 \mu \mathrm{m}$ and maximum temperature of $350^{\circ} \mathrm{C}$. The front inlet type was split/splitless with a split mode of $20: 1$ with an inlet temperature of $200^{\circ} \mathrm{C}$. Helium gas of $99.95 \%$ purity was used as carrier gas at a constant flow rate of $1.51 \mathrm{ml} / \mathrm{min}$. The initial oven temperature of $70^{\circ} \mathrm{C}$ was maintained for $2 \mathrm{~min}$ and ramped at $10^{\circ} \mathrm{C} / \mathrm{min}$ to $300^{\circ} \mathrm{C}$ and held at $300^{\circ} \mathrm{C}$ for $0.5 \mathrm{~min}$. Transfer line temperature was $260^{\circ} \mathrm{C}$.

The mass spectrometer method acquisition delay of $4 \mathrm{~min}$, mass range of between 40 and $450 \mathrm{~m} / \mathrm{z}$, with an acquisition rate of 10 spectra/second and electron energy (ionization energy) of $-70 \mathrm{eV}$ was used. The ion source temperature was $250^{\circ} \mathrm{C}$. Data processing method base line offset of 1 (just above the noise) was used, with a peak width of $4 \mathrm{sec}$ and signal to noise $(\mathrm{S} / \mathrm{N})$ ratio of 500 . The library search mode was normal and forward. The number of library hit was 10 , while the minimum molecular weight allowed was 40 and maximum molecular weight was 450 . Mass threshold was $2 \%$, and minimum similarity before name was assigned was $50 \%$. The library used was Replib and Mainlb from NIST.

The ${ }^{1} \mathrm{H}$ NMR and ${ }^{13} \mathrm{C}$ NMR analyses of the pyrolytic oil were performed using the Bruker Advance III 400 equipment operating at $400.132 \mathrm{MHz}$ for ${ }^{1} \mathrm{H}$ and $100.623 \mathrm{MHz}$ for

${ }^{13} \mathrm{C}$. Samples were prepared in $5 \mathrm{ml} \mathrm{NMR}$ tubes using $\mathrm{PDCl}_{3}$ as solvent.

\section{Results and Discussion}

3.1. Proximate and Ultimate Analyses and GCV of Raw Materials. The used tire sample representative was characterized for proximate and ultimate analysis and determination of HHV. Results obtained are shown in Table 3.

Identification of the sample material composition in terms of volatile matter, fixed carbon content, moisture content, and ash content was done by proximate analysis. The obtained results indicate the suitability of the raw material for the pyrolysis process as it was within the value range for the tire pyrolyzed by Song et al. [30]. Moreover, the results are in agreement with the literature $[10,15,31-33]$. Nevertheless, comparison with other samples $[15,30,31]$ revealed a substantial variance in the ash content. Such could be attributed to the difference in the amount of inorganic compounds (clay, zinc, silica, stabilizers, antioxidants, and other additives) introduced into the tire rubber during production subject to the manufacturers exclusive formulation $[5,34,35]$. Thus, the ash content is composed mainly of inorganic residue after the combustion of the volatile material and fixed carbon. Although the presence of fixed carbon content indicates the amount of char formation in the pyrolysis process [36], it does not signify the total carbon 


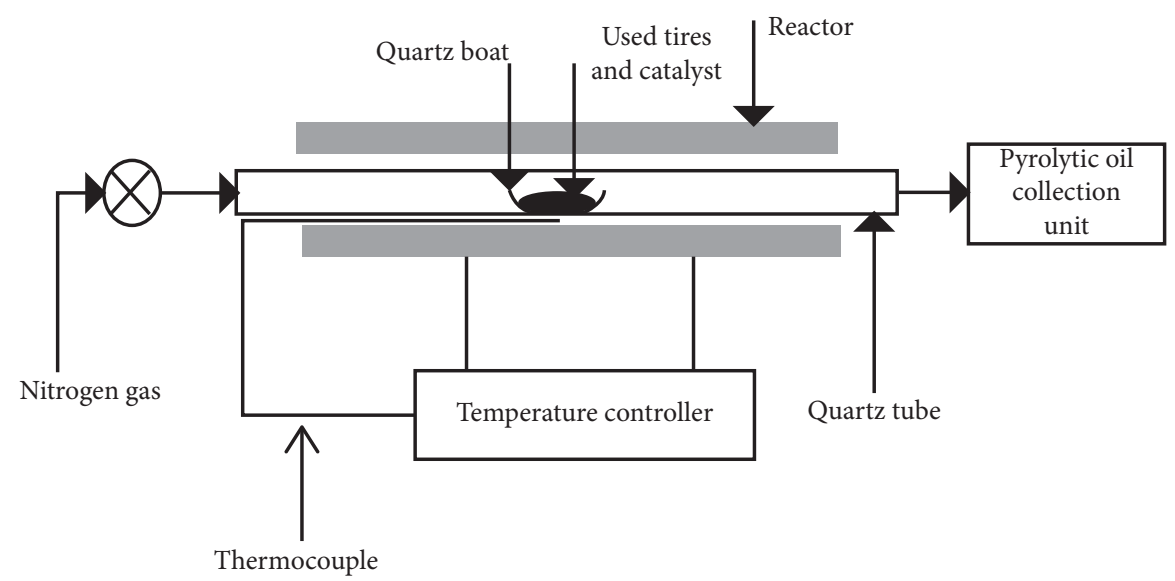

FIGURE 1: Schematic of the experimental setup for the pyrolysis of used tires.

TABLE 2: Standard methods for physical property analysis.

\begin{tabular}{|c|c|c|}
\hline Physical property & Method & Process description \\
\hline Density & ASTM D1298-12b & $\begin{array}{l}\text { Use of a hydrometer placed in a constant temperature } \\
\text { bath. }\end{array}$ \\
\hline Kinematic viscosity & ASTM D445-15 & $\begin{array}{c}\text { Use of a calibrated glass viscosity tube submerged in a } \\
\text { water bath at } 40^{\circ} \mathrm{C} \text {. }\end{array}$ \\
\hline Flash point & ASTM D93-15a & $\begin{array}{l}\text { Use of the Pensky-Martens closed test cup filled up to } \\
\text { its mark with the test sample. The temperature shall } \\
\text { be at least } 18^{\circ} \mathrm{C} \text { below the expected flash point for the } \\
\text { test sample and the cup. }\end{array}$ \\
\hline Pour point & ASTM D97-15 & $\begin{array}{l}\text { Use of the test jar glass that held the sample. Samples } \\
\text { are first heated and then cooled at a specific rate at } \\
\text { decrements of } 3^{\circ} \mathrm{C} \text {. The temperature } 3^{\circ} \mathrm{C} \text { above the } \\
\text { point the oil stops moving is noted as the pour point. }\end{array}$ \\
\hline Higher heating value & ASTM -E711 & $\begin{array}{l}\text { Use of the Parr oxygen bomb calorimeter. } \\
\text { Method based on measurement of the specific }\end{array}$ \\
\hline Sulphur content & ASTM D7039-15a & $\begin{array}{l}\text { wavelength from excitation of sulphur, which can } \\
\text { accurately measure the concentrations of sulphur } \\
\text { from } 2 \text { to } 500 \mathrm{ppm} \text {. }\end{array}$ \\
\hline
\end{tabular}

TABLE 3: HHV and ultimate and proximate analyses of used tires.

\begin{tabular}{lccc}
\hline & $\begin{array}{c}\text { Present study } \\
\text { Used tire }\end{array}$ & $\begin{array}{c}\text { Gonzlez et al. [10] } \\
\text { Car tire }\end{array}$ & $\begin{array}{c}\text { Kar [15] } \\
\text { Car tire }\end{array}$ \\
\hline Proximate analysis (\%) & & & 0.7 \\
Moisture content & 0.5 & 8.0 & 1.72 \\
Ash & 16.0 & 29.5 & 19.13 \\
Fixed carbon & 27.1 & 61.9 & 19.45 \\
Volatile content & 56.4 & & 59.69 \\
\hline Ultimate analysis (\%) & & 86.7 & 67.08 \\
Carbon $(\mathrm{C})$ & 85.0 & 8.10 & 6.12 \\
Hydrogen (H) & 5.5 & 0.4 & 0.17 \\
Nitrogen (N) & 0.21 & 1.40 & 2.05 \\
Sulphur (S) & 1.2 & 1.30 & 24.58 \\
Oxygen (O) & 8.09 & 36.20 & 27.37 \\
GCV $(\mathrm{MJ} / \mathrm{kg})$ & 31.22 & & \\
\hline
\end{tabular}

in the feedstock as some might have escaped along with the volatiles during the thermal decomposition.

For the ultimate analysis, the results of hydrogen $(\mathrm{H})$ and nitrogen $(\mathrm{N})$ contents reported correlate with values reported in literature [35], but a little small variation was observed in the values obtained for $\mathrm{C}$ and $\mathrm{S}$ contents. The lower moisture and ash content recorded for the used tires could be an added advantage than coal as a solid fuel [37]. 
Moreover, the gross calorific value, GCV, of used tires $(31.22 \mathrm{MJ} / \mathrm{kg})$ obtained in this study was lower than that of conventional diesel $(44.80 \mathrm{MJ} / \mathrm{kg})$ but higher than that of lignite coal $(15.0 \mathrm{MJ} / \mathrm{kg})$ and wood $(21.7 \mathrm{MJ} / \mathrm{kg})$, making used tires a better source of solid fuel than lignite coal and wood [5].

\subsection{Thermogravimetric analysis (TGA) and Differential} Thermogravimetry (DTG) of the UT. Thermogravimetric analysis (TGA) and differential thermogravimetry (DTG) are the thermal analysis method, which helps in the study of the degradation behavior of materials during heating. It investigates the mass variation of sample as a function of time and temperature $[38,39]$.

The TGA and DTG thermograms of the studied material are illustrated in Figure 2. Two thermal degradation zones were observed for the studied temperature range of 30 to $800^{\circ} \mathrm{C}$. A similar observation has been reported in literature $[2,32]$. From the TGA curve, the first stage of thermal degradation occurred between the temperature range of 30 to $353^{\circ} \mathrm{C}$. This could be attributed to the loss of volatile components such as moisture, oil, and other additives present in the tire. Similarly, the second stage degradation, which is regarded as an active pyrolytic zone, occurred at a temperature range of 353 to $520^{\circ} \mathrm{C}$, attributable to the continuous cracking, and rapid degradation of the rubber components (such as natural rubber (NR), styrenebutadiene rubber (SBR), and butadiene rubber (BR)) present in the material $[36,39]$. At this point, heavy molecular weight hydrocarbons are depolymerized and hydrogenated/dehydrogenated into lower weight hydrocarbon molecules in the form of liquid and gas phase. Above this temperature, the sample is mainly left as ash as indicated by the constant weight loss on the TGA/DTG curves. Both stages accounted for about $60 \%$ mass loss of the studied tire rubber leaving about $40 \%$ solid residue mass close to the sum value of ash and fixed carbon recorded for the proximate analysis in Table 3.

On the contrary, the DTG curve shows two dominant peaks at $386^{\circ} \mathrm{C}$ and $425^{\circ} \mathrm{C}$ for the UT rubber. When these results are compared with values of thermal degradation of individual kind of rubbers in literature [35, 40], NR degrades at about $375^{\circ} \mathrm{C}, \mathrm{SBR}$ at about $445^{\circ} \mathrm{C}$, and $\mathrm{BR}$ at about $465^{\circ} \mathrm{C}$, revealing that the first peak could be attributed to the degradation of NR and the second dominant peak indicates the degradation of SBR and BR a major type of polymer in car tire formulation. From the dominant peaks indicated on the DTG curve, significant conversion and secondary depolymerisation took place during the second stage.

\subsection{Catalytic Pyrolysis of Used Tires with the Synthesized} Zeolite NaY Catalyst. The catalytic pyrolysis of used tires was conducted at optimum operating conditions (operating temperature of $600^{\circ} \mathrm{C}$, heating rate of $15^{\circ} \mathrm{C} / \mathrm{min}$, and a particle size of $6 \mathrm{~mm}$ ) obtained in our previous study [5] using synthesized zeolite $\mathrm{NaY}$ as a catalyst. The catalyst utilization was to improve product yield of used tires rubber pyrolysis at optimum temperature with interest on the liquid fraction. The catalyst-to-used tires ratio range investigated

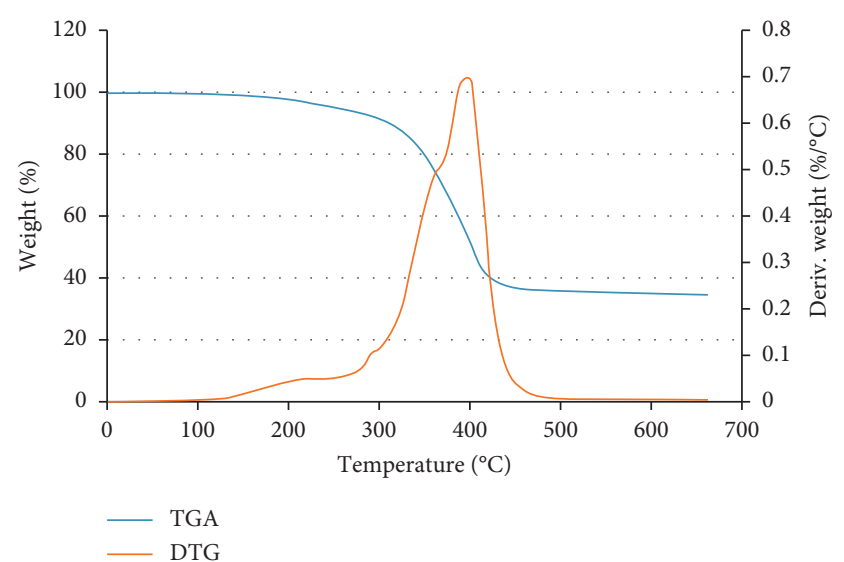

Figure 2: TGA and DTG curves of UT at $15^{\circ} \mathrm{C} / \mathrm{min}$.

was from 1 to $10 \mathrm{wt} . \%$ of the catalyst concentration to the feedstock (at a constant amount of $10 \mathrm{~g} / \mathrm{batch}$ of used tires). Figure 3 illustrates the effect of the zeolite $\mathrm{NaY}$ weight percent on the product yield of used tires pyrolysis. The data plotted are the mean value and standard deviation of the pyrolytic oil, char, and gas yields for the varied catalyst concentration.

From Figure 3(a), the effect of catalyst from 1 to $10 \mathrm{wt} . \%$ did not display a consistent increase on the liquid yield; however, it resulted in an optimum liquid yield (21.3 wt.\%) at $7.5 \mathrm{wt} . \%$ with a decline in gas yield (from 43.93 to $37.57 \mathrm{wt} . \%)$ and a rise to a constant char yield ( $\sim 38.3 \mathrm{wt} . \%)$ beyond this ratio. Based on the product yield curve, the effect will be discussed in two sections: catalyst-to-used tires ratio 1 to $5 \mathrm{wt} . \%$ and 5 to $10 \mathrm{wt} . \%$. For the catalyst-to-tires ratio 1 to $5 \mathrm{wt} . \%$, there was a steady increase for gas from 43.93 to $45.83 \mathrm{wt} . \%$ and solid char yield from 35.07 to $36.40 \mathrm{wt} . \%$ with a decrease in pyrolytic oil yield (21.0 to $17.30 \mathrm{wt} . \%)$ till $5 \mathrm{wt} . \%$ ratio.

The gradual rise in gas yield could be ascribed to the role of the catalyst enabling the speedy liberation of moisture content, plasticizers, volatile matters in the material, and cracking of noncondensable light short-chain hydrocarbons in the oil leading to a reduction in oil yield [15].

On the contrary, for catalyst-to-UT ratio of 5 to $10 \mathrm{wt} . \%$, a gradual increase in pyrolytic oil yield from 17.30 to 21.30 and solid residue yield from 36.40 to $42.10 \mathrm{wt} . \%$ with a decrease in gas yield from 45.83 to $37.57 \mathrm{wt}$ \% was observed. The increase in pyrolytic oil yield could have resulted from the catalyst actively enhancing the cracking of the volatile material, repolymerisation of gaseous hydrocarbon compounds into more condensable gases, and depolymerisation of carbon components into liquid formation [14, 21, 41].

This optimum pyrolytic oil yield of $21.30 \pm 1.41 \mathrm{wt} . \%$ at catalyst-to-tire ratio of $7.5 \mathrm{wt} . \%$ obtained from the catalytic pyrolysis of used tires using synthesized zeolite $\mathrm{NaY}$ from kaolin was less than that obtained $(34.40 \pm 2.18 \mathrm{wt} . \%)$ for the thermal pyrolysis of used tires at same process conditions in a previous investigation [5]. Such a decrease in pyrolytic oil yield was likewise observed by other researchers $[13,16,24,42,43]$. In the study conducted by Pradhan et al. [41] on catalytic pyrolysis of used tires and tube rubbers at 


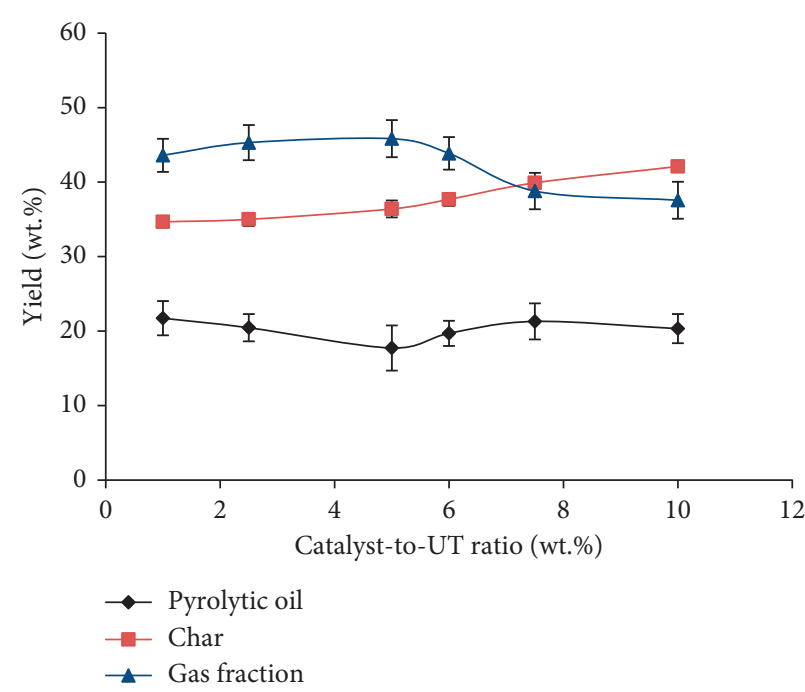

(a)

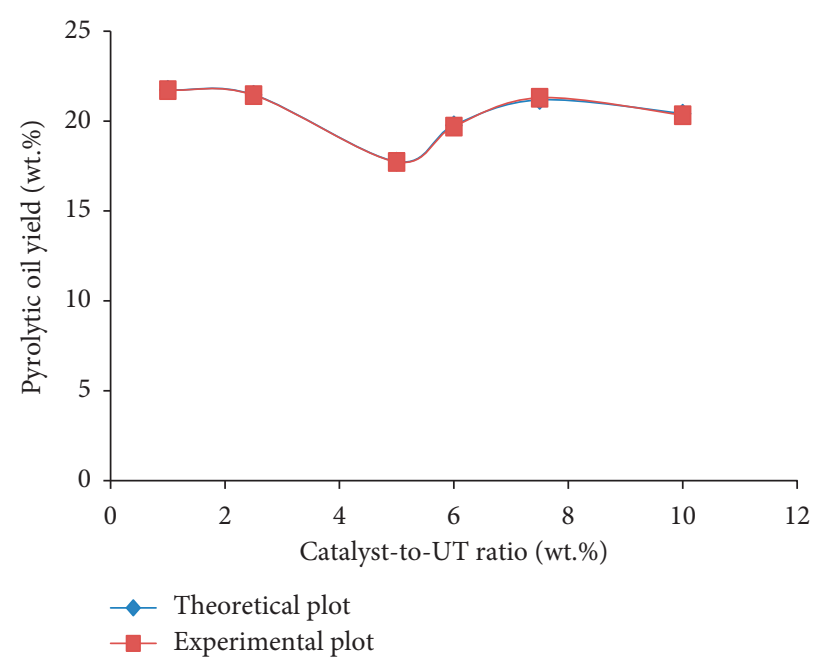

(b)

FIgURE 3: (a) Catalyst concentration effect on UT pyrolysis at $600^{\circ} \mathrm{C}(\mathrm{STD}$ : pyrolytic oil $=1.41$, char $=2.91$, and gas $=3.46)$. $(\mathrm{b})$ Experimental and theoretical plot of the catalyst effect on UT pyrolytic oil production.

600 and $700^{\circ} \mathrm{C}$ using $\mathrm{SiO}_{2}-\mathrm{AlO}_{2}$ Kaolin, $\mathrm{CaO}$, and $\mathrm{MgO}$ catalyst, a decrease in pyrolytic oil yield was reported. The authors reported that none of the catalysts used showed significant effect in increasing the oil yield compared to the thermal pyrolysis of the studied materials. Similarly, in the two-staged pyrolysis of used tires using catalysts reported by Shen et al. [22], the authors observed that the presence of the zeolite USY catalyst caused a reduction in the oil yield and an increase in gas yield with coke formation on the catalyst.

It is worthy of note that the increase in solid residue observed for the entire catalyst-to-tire range of the range studied must have resulted from the increase in catalyst weight (residues from reaction) that was homogeneously mixed with the feed material before pyrolysis [23].

Furthermore, predictability of the effect of catalyst concentration on the production behavior of pyrolytic oil from used tires modeling was performed using the Eureqa Nutonian software. A well-fitted theoretical plot with the experimental data was obtained using the following equation, as shown in Figure 3(b):

$$
Y=23.16-0.49 A-3.15 \sin (4.78+1.80 A),
$$

where $Y=$ pyrolytic oil yield and $A=$ catalyst concentration.

Figure 3(b) compares the experimental and the theoretical plots with $R^{2}$ goodness of fit $=0.99$, correlation coefficient $=0.99$, maximum error $=0.12$, mean squared error $=0.01$, mean absolute error $=0.06$, and complexity $=16$. This model outcome of the pyrolytic oil yield from catalytic pyrolysis of used tires confirms the efficiency of the fixed-bed reactor process and accuracy of predicting pyrolytic oil yield at the varied catalyst concentration using equation (1).

3.4. Characterisation of Produced Catalytic Pyrolysis Oil. The produced pyrolytic oil from the catalytic pyrolysis of used tires was characterized for fuel properties and chemical composition using standard methods and techniques with details discussed below:

3.4.1. Influence of Synthesized Zeolite NaY on Pyrolytic Oil Fuel Properties. One of the main applications of the pyrolytic oil is to serve as the fuel source; hence, the fuel properties (such as density, viscosity, flash point, pour point, $\mathrm{pH}$ value, sulphur content, refractive index, and HHV) were determined using ASTM methods. This will certainly unravel the influence of the synthesized catalyst on the pyrolytic oil property as liquid fuel and potentials for other purposes. Table 4 depicts the fuel properties determined for the catalyzed pyrolytic oil (CPO).

From the results in Table 4, the zeolite $\mathrm{NaY}$ catalyst had no significant effect on the density, viscosity, pour point, and flash point of the CPO compared with reports available for noncatalyzed pyrolytic oil in the literature $[5,41]$. Nevertheless, the values for the CPO density $\left(886 \pm 0.05 \mathrm{~kg} / \mathrm{m}^{3}\right)$ and viscosity $(5.15 \mathrm{cSt})$ were higher than that of commercial no. 2 diesel oil [36]. This could be attributed to the unrefined state of the CPO composed of heavy molecular weight compounds, which resulted in higher density viscosity and pour point with a lower flash point than the commercial no. 2 diesel.

On the contrary, changes were observed for the CPO fuel properties such as refractive index, HHV, $\mathrm{pH}$ value, and sulphur content. Refractive index of 1.514 for the $\mathrm{CPO}$ was lower than the noncatalyzed pyrolytic oil and closer to that of commercial no. 2 diesel oil (1.45-1.475). This could be associated to the catalyst improving the yield of hydrocarbon compounds (within the lighter carbon range) than the noncatalyzed oil. Such improvement in the refractive index is an indicator that the oil will have a better autoignition performance $[5,44]$.

The $\mathrm{pH}$ value (5.46) and sulphur content $(1.35 \pm 0.05$ wt. $\%)$, which have a measure of influence on the 
TABLE 4: Fuel properties determined for the catalyzed pyrolytic oil (CPO).

\begin{tabular}{|c|c|c|c|c|c|c|}
\hline Fuel properties & $\begin{array}{l}\text { This study (catalyzed } \\
\text { pyrolytic oil) }\end{array}$ & Osayi et al. [5] & Pradhan and Singh [41] & {$[36]$} & Light fuel oil & Commercial no. 2 diesel \\
\hline Density $\left(\mathrm{kg} / \mathrm{m}^{3}\right)$ & $886 \pm 0.05^{\mathrm{a}}$ & $890 \pm 0.05^{\mathrm{a}}$ & $917.9^{\mathrm{b}}$ & 970 & 890 & $820-860$ \\
\hline Viscosity (cSt) & $5.15 \mathrm{cSt}^{\mathrm{d}}$ & $5.18^{\mathrm{d}}$ & $5.31^{\mathrm{d}}$ & $4.90^{\mathrm{d}}$ & $21^{\mathrm{c}}$ & $2.0-4.5^{\mathrm{d}}$ \\
\hline Refractive index & 1.514 & 1.520 & - & $\mathrm{N} / \mathrm{A}$ & - & $1.45-1.475$ \\
\hline Flash point $\left({ }^{\circ} \mathrm{C}\right)$ & $\leq 30$ & $\leq 30$ & & $\leq 32$ & 79 & $>55$ \\
\hline Pour point $\left({ }^{\circ} \mathrm{C}\right)$ & -12 & -12 & -87 & -3 & - & -40 to -30 \\
\hline $\mathrm{pH}$ value & 5.46 & 5.76 & - & 4.80 & - & N/A \\
\hline Sulphur content (wt.\%) & $1.35 \pm 0.05$ & $0.035 \pm 0.004$ & 1.38 & 1.36 & 1.4 & 1.2 \\
\hline $\mathrm{HHV}(\mathrm{MJ} / \mathrm{kg})$ & $42.80 \pm 0.37$ & $42.72 \pm 0.05$ & 34.61 & 40.80 & 44.8 & $44.0-46.0$ \\
\hline
\end{tabular}

$\mathrm{a}=20^{\circ} \mathrm{C} ; \mathrm{b}=15^{\circ} \mathrm{C} ; \mathrm{c}=30^{\circ} \mathrm{C} ; \mathrm{d}=40^{\circ} \mathrm{C}$.

acidity and corrosiveness of the oil, were more for the $\mathrm{CPO}$ than the noncatalyzed pyrolytic oil produced from the same used tire rubber [5]. Such a reduction in the $\mathrm{pH}$ value observed for the CPO must have resulted from the catalyst having a preventive effect on the sulphur compounds in the used tires from escaping with the volatile matter during pyrolysis thereby being trapped in the liquid fraction. However, the values are within the range of $\mathrm{pH}$ and sulphur content [38] and will not enhance corrosion of storage facilities and internal parts of combustion engine by the $\mathrm{CPO}$ [45].

The higher heating value, which is a key factor in determining the energy content of a material, was determined for the CPO. A value of $42.80 \pm 0.37 \mathrm{MJ} / \mathrm{kg}$ was observed for the $\mathrm{CPO}$, which is close to that of commercial fossil fuel $(44.0-46.0 \mathrm{MJ} / \mathrm{kg})$. Such high heating value and improved fuel properties observed from the use of the synthesized zeolite $\mathrm{NaY}$ makes the $\mathrm{CPO}$ a viable alternative source of liquid fuel or as petroleum refinery feedstock $[15,46]$.

\subsubsection{Influence of Synthesized Zeolite NaY on Chemical} Composition of Pyrolytic Oil. To ascertain the change in chemical composition of the pyrolytic oil with respect to the synthesized catalyst-to-tire ratio, the $\mathrm{CPO}$ was analyzed using standard techniques such as FT-IR, NMR, and GCMS. The FT-IR was used to identify the functional group composition of the $\mathrm{CPO}$, and the results in comparison with other study are represented in Table 5. The CPO obtained for the different weights of $1,5,7.5$, and $10 \mathrm{wt} . \%$ catalyst-to-tire ratio gave a similar FT-IR spectrum (Figures 4(a) and 4(b)), indicating the presence of similar functional groups in the derived oil. However, the double bonds $\left(2000-1500 \mathrm{~cm}^{-1}\right)$ region of the $\mathrm{CPO}$ was observed to be stronger than that of the noncatalyzed pyrolytic oil [5]. This shows a possible occurrence of the transformation of hydrocarbon compounds in the pyrolytic oil due to the presence of the catalyst. In addition, the fingerprint region skeletal vibrations $\left(1500-500 \mathrm{~cm}^{-1}\right)$ of the CPO were not different from that of the noncatalyzed pyrolytic oil. Such was expected, as the same material pyrolyzed (catalytic and noncatalytic pyrolysis) would retain its fingerprint region skeletal vibration. A comparison of the FT-IR results of the $\mathrm{CPO}$ with reports in literature reveals the oil to be mainly of aliphatic and aromatic compounds with the presence of other hydrocarbon compounds in low proportion $[10,47,48]$. This reveals the possibility of the CPO as a source of fuel or chemical feedstock $[8,15,23]$.

The CPO and noncatalyzed pyrolytic oil ${ }^{1} \mathrm{H}$ NMR and ${ }^{13} \mathrm{C}$ NMR analyses were performed in order to determine the effect of the catalyst on the hydrocarbon composition. The data results from the NMR spectrum are presented in Table 6. From the protons and carbon contents results, it was observed that the various $\mathrm{CPO}$ and noncatalyzed pyrolytic oil produced is a mixture of aromatics, olefins, paraffins, and a small amount of alcohols (species containing the hydroxyl group). These results were in accordance with other research studies in the literature $[2,4,15]$.

However, the CPO of $1 \mathrm{wt} . \%$ presented a $3.71 \%$ increase in the aromatic group (9.0-6.5 ppm chemical shift range) and $5.61 \%$ increase in the aliphatic adjacent to the aromatic/ alkene group (3.3-1.8 ppm chemical shift range) than the noncatalyzed pyrolytic oil. Furthermore, it was observed that the CPO for 1, 5, 7.5, and $10 \mathrm{wt} . \%$ had an increase of more than $36.36 \%$ and $11.96 \%$ in the aliphatic adjacent to the oxygen/hydroxyl group (4.5-3.3 ppm chemical shift range) and olefinic or phenolic group (4.5-3.3 ppm chemical shift range) than that of noncatalyzed pyrolytic oil. Although the noncatalyzed pyrolytic oil had a higher value for other aliphatic bonded to aliphatic only (1.8-0.4 ppm chemical shift range), the difference was not less than $1 \%$ compared to the least recorded value for CPO.

For the carbon types, the CPO for 1, 5, 7.5, and $10 \mathrm{wt} . \%$ had more aliphatic carbon than the noncatalyzed pyrolytic oil, while the aromatic carbon types of the noncatalyzed pyrolytic oil were higher than that obtained for all the CPO.

GC-MS analysis was conducted on the CPO $(1,5,7.5$, and $10 \mathrm{wt} . \%)$ and noncatalyzed pyrolytic oil in order to investigate the effect of the catalyst on the industrial chemical compounds and carbon range (of gasoline, kerosene, and diesel) yield. The pyrolytic oil derived compounds chromatogram peaks were analyzed with NIST search software, with over 400 compounds identified. The compounds identified in this study are in accordance with that published in the literature [22, 23, 49].

Table 7 represents the influence of the catalyst activity on the pyrolytic oil yield of some chemical compounds of industrial significance. From the results, all the CPO gave a benzene yield higher than that of noncatalyzed pyrolytic oil. This can be ranked as $\mathrm{CPO}(5 \mathrm{wt} . \%)>\mathrm{CPO}(1 \mathrm{wt} . \%)>\mathrm{CPO}$ 
TABLE 5: FTIR functional groups and the indicated compounds of this study pyrolytic oil with other pyrolysis liquids.

\begin{tabular}{lccccc}
\hline \multicolumn{5}{c}{ Wavelength } \\
number $\left(\mathrm{cm}^{-1}\right)$ & & & \\
This study & {$[36]$} & {$[10]$} & {$[47]$} & Functional groups & Class of compounds \\
\hline- & - & $3600-3250$ & - & O-H stretching & Alcohols, phenols, or carboxylic acids \\
- & - & $3250-3100$ & - & C-H stretching & Aromatic compounds \\
- & $3100-3005$ & - & - & C=C stretching & Alkenes \\
$3000-2800$ & $3000-2800$ & $3000-2800$ & $3000-2800$ & C-H stretching & Alkanes \\
$1750-1700$ & - & - & $1750-1650$ & C=O & Aldehydes or ketones \\
$1650-1635$ & $1680-1635$ & $1670-1580$ & $1675-1575$ & C=C stretching & Alkenes \\
- & $1600-1530$ & $1600-1500$ & $1625-1575$ & Carbon-carbon stretching & Aromatic compounds \\
$1451-1375$ & $1520-1115$ & $1480-1360$ & $1475-1350$ & C-H bending & Alkanes \\
$1155-1016$ & - & $1150-1000$ & - & C-H in-plane bending & Aromatic compounds \\
$965-795$ & $1030-835$ & $960-870$ & $950-875$ & C=C stretching & Alkenes \\
$630-609$ & $830-655$ & $900-675$ & $900-675$ & C-H out-of-plane bending & Aromatic compounds \\
\hline
\end{tabular}

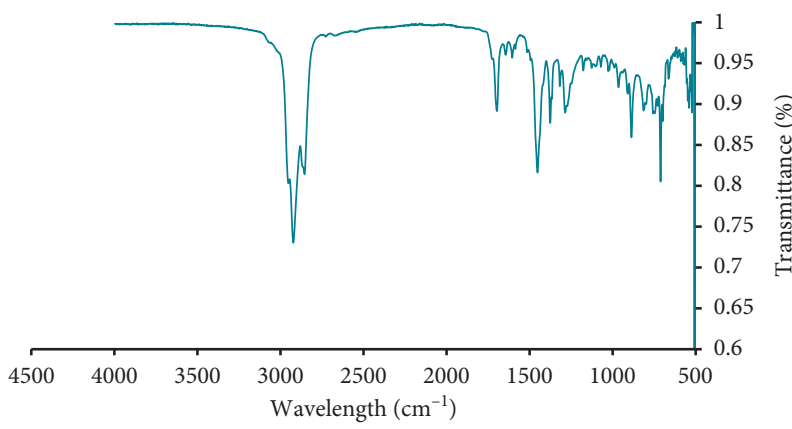

(a)

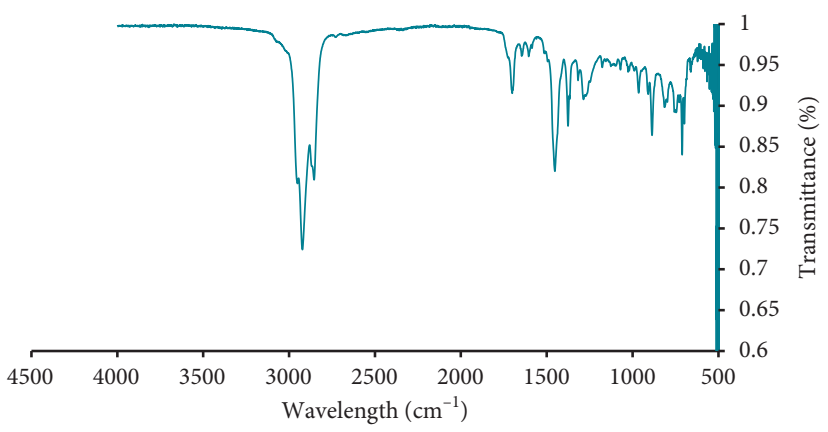

(b)

FIGURE 4: (a) FTIR transmittance spectrum for used tires pyrolytic oil. (b) FTIR transmittance spectrum of catalyzed pyrolytic oil from used tires.

TABLE 6: ${ }^{1} \mathrm{H}$ and ${ }^{13} \mathrm{C}$ NMR results for various catalysts-to-used tire pyrolytic oil obtained at $600^{\circ} \mathrm{C}$.

\begin{tabular}{|c|c|c|c|c|c|c|}
\hline \multirow[b]{2}{*}{ Types of hydrogen } & \multirow[b]{2}{*}{$\begin{array}{l}\text { Chemical shift } \\
(\mathrm{ppm})\end{array}$} & \multicolumn{5}{|c|}{ Percent of total hydrogen (mol \%) } \\
\hline & & $\begin{array}{c}\text { Noncatalyzed } \\
\text { pyrolytic oil }\end{array}$ & $\begin{array}{c}\mathrm{CPO} \\
\text { (1 wt.\% catalyst) }\end{array}$ & $\begin{array}{c}\text { CPO } \\
\text { (5 wt.\% catalyst) }\end{array}$ & $\begin{array}{c}\text { CPO } \\
\text { (7.5 wt.\% catalyst) }\end{array}$ & $\begin{array}{c}\text { CPO } \\
\text { (10 wt. } \% \text { catalyst })\end{array}$ \\
\hline Aromatic & $9.0-6.5$ & 7.0 & 7.26 & 6.81 & 7.12 & 6.60 \\
\hline $\begin{array}{l}\text { Phenolic }(\mathrm{OH}) \text { or olefinic } \\
\text { portion }\end{array}$ & $6.5-4.5$ & 5.60 & 6.80 & 6.98 & 6.27 & 6.67 \\
\hline $\begin{array}{l}\text { Aliphatic adjacent to } \\
\text { oxygen/hydroxyl group }\end{array}$ & $4.5-3.3$ & 0.66 & 0.40 & 1.00 & 0.93 & 0.99 \\
\hline $\begin{array}{l}\text { Aliphatic adjacent to } \\
\text { aromatic/alkene group }\end{array}$ & $3.3-1.8$ & 21.75 & 23.02 & 21.58 & 21.23 & 21.60 \\
\hline $\begin{array}{l}\text { Other aliphatics (bonded } \\
\text { to aliphatic only) } \\
\text { Types of carbon }\end{array}$ & $1.8-0.4$ & 64.94 & 64.53 & 63.99 & 64.45 & 64.13 \\
\hline Aliphatics & $75.0-5.0$ & 67.59 & 69.04 & 67.75 & 68.41 & 68.80 \\
\hline Aromatics & $185.0-100$ & 32.41 & 30.96 & 32.25 & 31.59 & 31.20 \\
\hline
\end{tabular}

$(10 \mathrm{wt} . \%)>\mathrm{CPO} \quad(7.5 \mathrm{wt} . \%)>$ noncatalyzed pyrolytic oil. This observed increase of benzene yield could be attributed to the catalyst ability to enhance chain scission that occurs mostly for the pyrolysis of the various components (NR, SBR, and BR) of used tires [50,51]. The investigation done by Chen and Qian [50] and Choi [51] further confirm that radicals, which are mostly subunits of the source rubber molecule, are formed as a result of the scission of the carbon bonds. Dodds et al. [52] also reported that highly reactive free radicals produced from the thermal degradation of rubber tire are the outcome of the scission of carbon bonds. In addition, the catalyst must have favored the mechanism known as the Diels-Alder reaction, a condition that promotes the generation of benzene ring chemical species at 
TABLE 7: Influence of zeolite NaY on pyrolytic oil chemical species.

\begin{tabular}{|c|c|c|c|c|c|}
\hline \multirow[b]{2}{*}{ Chemical species } & \multicolumn{5}{|c|}{ Concentration (area \%) } \\
\hline & $\begin{array}{c}\text { Noncatalyzed } \\
\text { pyrolytic oil }\end{array}$ & CPO (1 wt.\% catalyst) & CPO (5 wt.\% catalyst) & CPO (7.5 wt.\% catalyst) & CPO (10 wt. $\%$ catalyst) \\
\hline Benzene & 1.94 & 11.34 & 11.86 & 9.10 & 10.68 \\
\hline Toluene & - & - & - & - & 0.19 \\
\hline Ethylbenzene & 0.19 & 1.59 & 0.21 & 0.01 & 0.28 \\
\hline$o$-Xylene & 0.07 & - & 0.46 & - & 0.33 \\
\hline$p$-Xylene & - & - & 1.07 & 1.95 & 1.24 \\
\hline Styrene & 0.08 & - & - & - & 0.80 \\
\hline Naphthalene & 2.64 & 2.59 & 2.01 & 2.96 & 2.66 \\
\hline Quinoline & 0.92 & 0.60 & 0.50 & 1.05 & 1.00 \\
\hline Pyrene & 0.46 & 0.06 & 0.09 & 0.03 & 0.07 \\
\hline Thiophene & 0.39 & 0.22 & 0.20 & 0.37 & 0.17 \\
\hline Limonene & 0.08 & 9.72 & 2.85 & 2.96 & 5.00 \\
\hline P-Cresol & 0.10 & 0.75 & 0.25 & 0.26 & 0.45 \\
\hline Phenol & 1.24 & 3.47 & 1.99 & 6.43 & 6.65 \\
\hline
\end{tabular}

higher temperature $[53,54]$. Figure 5 shows the reaction route of benzene formation.

The catalyst also improved the yield of other valuable chemicals such as ethylbenzene, $o$ - and $p$-xylene, styrene, toluene, quinoline, pyrene, thiophene, P-cresol, phenol, and limonene. These could be attributed to the catalyst-cracking ability of the tire molecules, dehydrogenation, and transalkylation reaction that occurred during the pyrolysis process $[16,55]$. The presence of phenol and limonene in high amount in the $\mathrm{CPO}$ is an advantage to the market value of the pyrolytic oil due to the wide industrial application of these compounds.

Figure 6 depicts the yield of carbon range obtained from the CPO (1, 5, 7.5, and $10 \mathrm{wt} . \%)$ and that of noncatalyzed pyrolytic oil from used tires. The carbon range has been grouped into six categories according to their number of carbon atoms: <C5, C6-C10, C11-C15, C16-C20, C21-C25, and $\mathrm{C} 26-\mathrm{C} 30$. This will enable comparison with commercial fuel fractions such as kerosene, gasoline, diesel, and heavy fuel carbon range. From the graph, a decrease in heavy molecular weight hydrocarbon range of C21-C30 particularly the C26-C30 was observed for the $\mathrm{CPO}(1,5,7.5$, and $10 \mathrm{wt} . \%)$, compared to the noncatalyzed pyrolytic oil. Similar observation was reported by Lin et al. [56] during the use of the five catalysts: $\mathrm{KOH}, \mathrm{H}_{2} \mathrm{SO}_{4}, \mathrm{H}_{3} \mathrm{BO}_{3}, \mathrm{ZnCl}_{2}$, and $\mathrm{FeSO}_{4}$ in the production of bio-oil from sewage sludge. All five catalysts were found to decrease the heavy weight hydrocarbon content in the bio-oil compared to that of noncatalyzed biooil.

However, the increase in catalyst weight $(1,5,7.5$ and $10 \mathrm{wt} . \%$ ) favored the yield of carbon range of C6-C15 (more than $80 \%)$ for all the CPO compared to the noncatalyzed pyrolytic oil. Excluding the CPO (1 wt.\%), the others enhanced reduction of the hydrocarbon range below $\mathrm{C} 5$. The results imply that the catalyst played a role in ensuring more cracking of the rubber components (polyisoprene structure) occurred during the pyrolysis process. This is in agreement with the outcome of the investigation conducted by Lopez et al. [57] and that of Adrados et al. [13] where inorganic materials played the role of a catalyst during cracking of

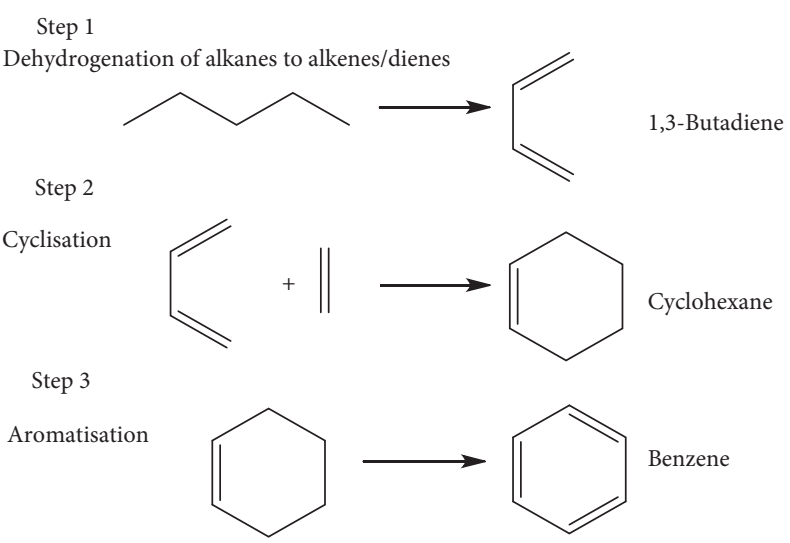

FIgURE 5: Diels-Alder reaction pathway for formation of the benzene ring $[53,54]$.

plastic waste materials. In both cases, lighter hydrocarbon range was obtained using the catalyst than the noncatalyzed pyrolytic oil.

Therefore, the catalyst has displayed the potential to increase the yield of carbon range (C6-C15), which is similar to petroleum fractions of gasoline (C6-C12) and kerosene (C11-C14), with lower yield of diesel and fuel oils (C11C20) compared to the noncatalyzed pyrolytic oil.

\section{Conclusion}

In this study, the effectiveness of the zeolite $\mathrm{NaY}$ catalyst synthesized from kaolin on improving the physicochemical properties of the pyrolytic oil derived from used tires (with a catalyst-to-tire ratio of 1 to $10 \mathrm{wt} . \%$ ) to attain commercial standard as chemicals and substitute fuel energy source was investigated. An increase in the catalyst weight gave a maximum pyrolytic oil yield of $21.3 \mathrm{wt} . \%$ at catalyst-to-tire ratio of $7.5 \mathrm{wt} . \%$. Although this was lower than the pyrolytic oil yield (34.40 wt.\%), for the noncatalyzed pyrolytic oil, the quality of the pyrolytic oil in terms of chemical composition and hydrocarbon fuel ranges varied from that of the 


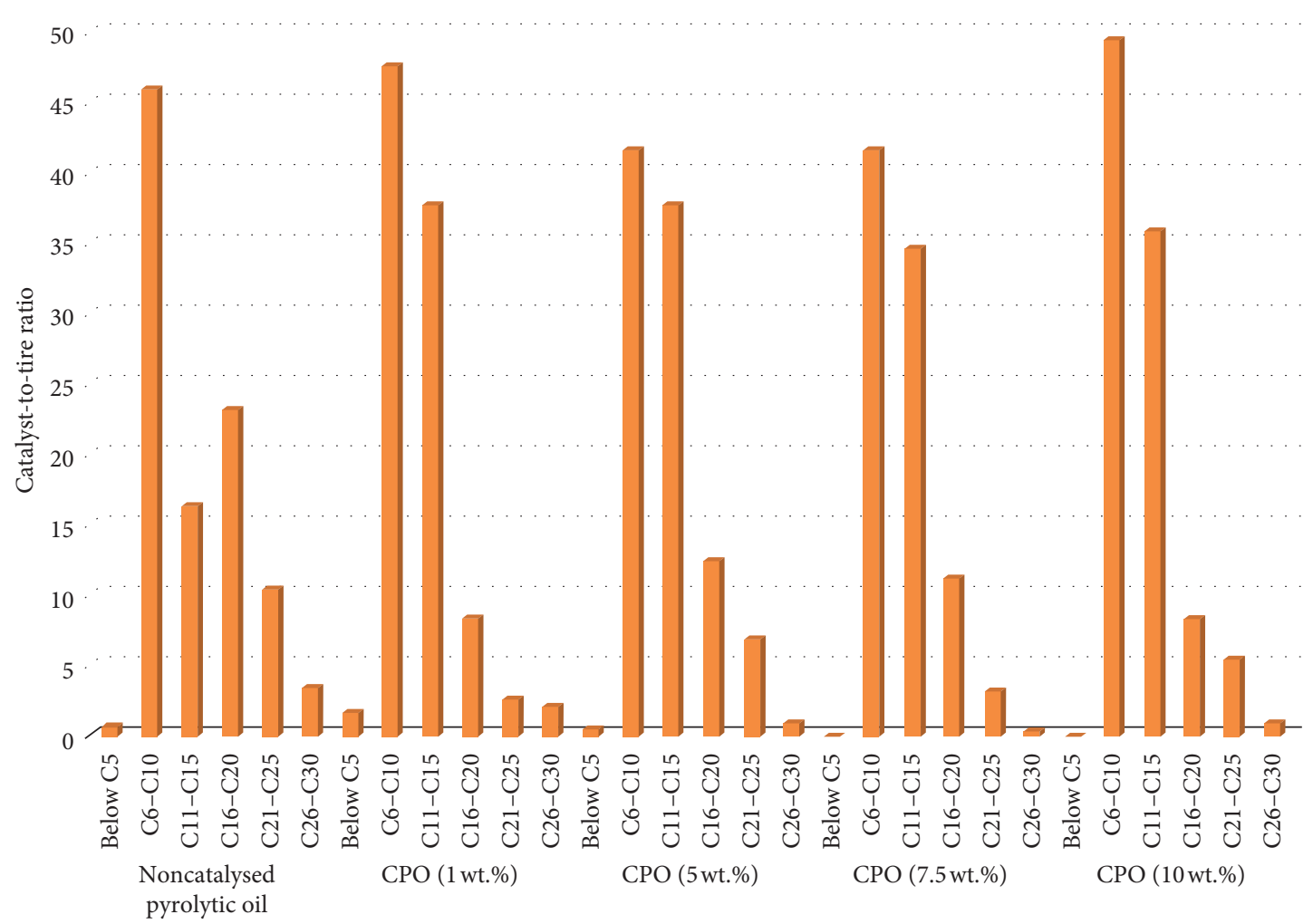

FIGURE 6: Effect of catalyst from GC-MS on carbon range in pyrolytic oil.

noncatalyzed pyrolytic oil, as indicated by the FT-IR, NMR, and GC-MS analysis.

The addition of the catalyst in the pyrolysis of used tires (at varied weight \%) gave a remarkable influence on the formation and content of some valuable industrial chemical compounds in the CPO. From the GC-MS result, all the CPO gave a benzene yield higher than that of noncatalyzed pyrolytic oil. This can be ranked as CPO (5 wt.\%) > CPO $(1 \mathrm{wt} . \%)>\mathrm{CPO}(10 \mathrm{wt} . \%)>\mathrm{CPO} \quad(7.5 \mathrm{wt} . \%)>$ noncatalyzed pyrolytic oil. In addition, the catalyst also improved the yield of other valuable chemicals such as ethylbenzene, $o$ - and $p$ xylene, styrene, toluene, quinoline, pyrene, thiophene, P-cresol, phenol, and limonene in the pyrolytic oil.

In terms of hydrocarbon range, the catalyst displayed the potential to increase the yield of carbon range (C6-C15) similar to petroleum fractions of gasoline (C6-C12) and kerosene (C11-C14), with lower yield of diesel and fuel oils (C11-C20) compared to the noncatalyzed pyrolytic oil.

Hence, the local material (kaolin) has shown effectiveness in the synthesis of the zeolite $\mathrm{NaY}$ catalyst that has substantially improved the yield of the industrial chemical compound from the pyrolytic oil with a hydrocarbon range likened to petroleum fraction of conventional gasoline and kerosene. Nevertheless, the analysis of the gaseous product will be for further studies.

\section{Data Availability}

The FT-IR, NMR, and GC-MS data and other data used to support the findings of this study are available from the corresponding author upon request.

\section{Disclosure}

The abstract of this research was accepted for presentation (not the manuscript) in ICSWDES 2018: 20th International Conference on Solid Waste Disposal and Environmental Sustainability; however, due to nonpayment of the registration fees, it was not presented in the conference.

\section{Conflicts of Interest}

The authors declare that there are no conflicts of interest regarding the publication of this paper.

\section{Acknowledgments}

Financial support from the National Research Foundation (NRF) under the South Africa NRF Focus Area and student bursaries made available by Vaal University of Technology is hereby acknowledged.

\section{References}

[1] H. Aydin and C. Ilkilic, "Analysis of combustion, performance and emission characteristics of a diesel engine using low sulfur tire fuel," Fuel, vol. 143, pp. 373-382, 2015.

[2] S. T. Kumaravel, A. Murugesan, and A. Kumaravel, "Tyre pyrolysis oil as an alternative fuel for diesel engines-a review," Renewable and Sustainable Energy Reviews, vol. 60, pp. 1678-1685, 2016.

[3] J. I. Osayi, S. Iyuke, and S. E. Ogbeide, "Biocrude production through pyrolysis of used tyres," Journal of Catalysts, vol. 2014, Article ID 386371, 9 pages, 2014. 
[4] C. İlkılıç and H. Aydin, "Fuel production from waste vehicle tires by catalytic pyrolysis and its application in a diesel engine," Fuel Processing Technology, vol. 92, no. 5, pp. 11291135, 2011.

[5] J. I. Osayi, S. Iyuke, M. O. Daramola, P. Osifo, I. J. van der Walt, and S. E. Ogbeide, "Pyrolytic conversion of used tyres to liquid fuel: characterisation and effect of operating conditions," Journal of Material Cycles and Waste Management, vol. 20, no. 2, pp. 1273-1285, 2017.

[6] J. I. Osayi, S. Iyuke, M. O. Daramola, P. Osifo, I. J. Van Der Walt, and S. E. Ogbeide, "Evaluation of pyrolytic oil from used tires and natural rubber (Hevea brasiliensis)," Chemical Engineering Communications, vol. 205, no. 6, pp. 805-821, 2018.

[7] M. Rofiqulislam, H. Haniu, and M. Rafiqulalambeg, "Liquid fuels and chemicals from pyrolysis of motorcycle tire waste: product yields, compositions and related properties," Fuel, vol. 87, no. 13-14, pp. 3112-3122, 2008.

[8] O. Onay and H. Koca, "Determination of synergetic effect in co-pyrolysis of lignite and waste tyre," Fuel, vol. 150, pp. 169-174, 2015.

[9] R. Sun, B.-Z. Zhu, and Y.-L. Sun, "Pyrolysis and reaction kinetics of automobile waste tire with TG-DSC-MS technique," Chinese Journal of Process Engineering, vol. 16, 2016.

[10] J. F. Gonzlez, J. M. Encinar, J. L. Canito, and J. J. Rodriguez, "Pyrolysis of automobile tyre waste. Influence of operating variables and kinetics study," Journal of Analytical and Applied Pyrolysis, vol. 58-59, pp. 667-683, 2001.

[11] N. M. Guo, B. Danon, P. van der Gryp, and J. F. Görgens, "Condensation of the hot volatiles from waste tyre pyrolysis by quenching," J. Anal. Appl. Pyrolysis, vol. 124, 2017.

[12] W. Namchot and S. Jitkarnka, "Catalytic pyrolysis of waste tire using HY/MCM-41 core-shell composite," Journal of Analytical and Applied Pyrolysis, vol. 121, pp. 297-306, 2016.

[13] A. Adrados, I. de Marco, B. M. Caballero, A. López, M. F. Laresgoiti, and A. Torres, "Pyrolysis of plastic packaging waste: a comparison of plastic residuals from material recovery facilities with simulated plastic waste," Waste Management, vol. 32, no. 5, pp. 826-832, 2012.

[14] M. M. Barbooti, T. J. Mohamed, A. A. Hussain, and F. O. Abas, "Optimization of pyrolysis conditions of scrap tires under inert gas atmosphere," Journal of Analytical and Applied Pyrolysis, vol. 72, no. 1, pp. 165-170, 2004.

[15] Y. Kar, "Catalytic pyrolysis of car tire waste using expanded perlite," Waste Management, vol. 31, no. 8, pp. 1772-1782, 2011.

[16] S. Muenpol, R. Yuwapornpanit, and S. Jitkarnka, "Valuable petrochemicals, petroleum fractions, and sulfur compounds in oils derived from waste tyre pyrolysis using five commercial zeolites as catalysts: impact of zeolite properties," Clean Technologies and Environmental Policy, vol. 17, no. 5, pp. 1149-1159, 2015.

[17] J. D. Martínez, A. Veses, A. M. Mastral et al., "Co-pyrolysis of biomass with waste tyres: upgrading of liquid bio-fuel," Fuel Processing Technology, vol. 119, pp. 263-271, 2014.

[18] W. Namchot and S. Jitkarnka, "Upgrading of waste tyrederived oil from waste tyre pyrolysis over $\mathrm{Ni}$ catalyst supported on HZSM-5 zeolite," Chemical Engineering Transactions, vol. 13, no. 3, 2015.

[19] A. Ayanoğlu and R. Yumrutaş, "Production of gasoline and diesel like fuels from waste tire oil by using catalytic pyrolysis," Energy, vol. 103, pp. 456-468, 2016.

[20] M. Kyari, A. Cunliffe, and P. T. Williams, "Characterization of oils, gases, and char in relation to the pyrolysis of different brands of scrap automotive tires," Energy \& Fuels, vol. 19, no. 3, pp. 1165-1173, 2005.

[21] M. Olazar, G. Lopez, M. Arabiourrutia, G. Elordi, R. Aguado, and J. Bilbao, "Kinetic modelling of tyre pyrolysis in a conical spouted bed reactor," Journal of Analytical and Applied Pyrolysis, vol. 81, no. 1, pp. 127-132, 2008.

[22] B. Shen, C. Wu, R. Wang, B. Guo, and C. Liang, "Pyrolysis of scrap tyres with zeolite USY," Journal of Hazardous Materials, vol. 137, no. 2, pp. 1065-1073, 2006.

[23] P. T. Williams and A. J. Brindle, "Aromatic chemicals from the catalytic pyrolysis of scrap tyres," Journal of Analytical and Applied Pyrolysis, vol. 67, no. 1, pp. 143-164, 2003.

[24] J. Shah, M. R. Jan, and F. Mabood, "Catalytic pyrolysis of waste tyre rubber into hydrocarbons via base catalysts," Iranian Journal of Chemistry and Chemical Engineering, vol. 27, 2008.

[25] M. Jahirul, M. Rasul, A. Chowdhury, and N. Ashwath, "Biofuels production through biomass pyrolysis -a technological review," Energies, vol. 5, no. 12, pp. 4952-5001, 2012.

[26] S. Kordoghli, M. Paraschiv, B. Khiari, F. Zagrouba, and M. Tazerout, "Using oxides of alkaline-earth metals as catalysts in used tyres pyrolysis," International Journal of ChemTech Research, vol. 9, 2016.

[27] C. S. Cundy and P. A. Cox, "The hydrothermal synthesis of zeolites: precursors, intermediates and reaction mechanism," Microporous and Mesoporous Materials, vol. 82, no. 1-2, pp. 1-78, 2005.

[28] S. Chandrasekhar, "Influence of metakaolinization temperature on the formation of zeolite 4A from kaolin," Clay Minerals, vol. 31, no. 2, pp. 253-261, 1996.

[29] J. I. Osayi, A Comparative Study between Pyrolytic Oil Obtained from Used Tyres and Natural Rubber, University of the Witwatersrand, Johannesburg, South Africa, 2016.

[30] Z. Song, Y. Yang, X. Zhao et al., "Microwave pyrolysis of tire powders: evolution of yields and composition of products," Journal of Analytical and Applied Pyrolysis, vol. 123, pp. 152-159, 2017.

[31] K. Ding, Z. Zhong, B. Zhang, Z. Song, and X. Qian, "Pyrolysis characteristics of waste tire in an analytical pyrolyzer coupled with gas chromatography/mass spectrometry," Energy and Fuels, vol. 29, no. 5, pp. 3181-3187, 2015.

[32] E. L. K. Mui, W. H. Cheung, and G. McKay, "Tyre char preparation from waste tyre rubber for dye removal from effluents," Journal of Hazardous Materials, vol. 175, no. 1-3, pp. 151-158, 2010.

[33] K. Wang, Y. Zheng, X. Zhu et al., "Thermal pyrolysis of bicycle waste tyre using batch reactor," Bioresource Technology, vol. 102, pp. 229-234, 2017.

[34] A. Undri, L. Rosi, M. Frediani, and P. Frediani, "Fuel from microwave assisted pyrolysis of waste multilayer packaging beverage," Fuel, vol. 133, pp. 7-16, 2014.

[35] P. T. Williams, "Pyrolysis of waste tyres: a review," Waste Management, vol. 33, no. 8, pp. 1714-1728, 2013.

[36] M. R. Islam, M. S. H. K. Tushar, and H. Haniu, "Production of liquid fuels and chemicals from pyrolysis of Bangladeshi bicycle/rickshaw tire wastes," Journal of Analytical and Applied Pyrolysis, vol. 82, no. 1, pp. 96-109, 2008.

[37] S. E. Iyuke, M. O. Daramola, P. Mokena, and A. Marshall, "Thermodynamic stability of graphitic diamond films produced from catalytic chemical vapour deposition reactor," Journal of Industrial and Engineering Chemistry, vol. 30, pp. 336-341, 2015.

[38] Y.-M. Chang, "On pyrolysis of waste tire: degradation rate and product yields," Resources, Conservation and Recycling, vol. 17, no. 2, pp. 125-139, 1996. 
[39] M. Juma, Z. Korenova, J. Markos, J. Annus, and L. Jelemensky, "Pyrolisis and combustion of scrap tyres," Petroleum \& Coal, vol. 48, pp. 15-26, 2006.

[40] A. Quek and R. Balasubramanian, "Liquefaction of waste tires by pyrolysis for oil and chemicals-a review," Journal of Analytical and Applied Pyrolysis, vol. 101, pp. 1-16, 2013.

[41] D. Pradhan and R. K. Singh, "Thermal pyrolysis of bicycle waste tyre using batch reactor," International Journal of Chemical Engineering and Applications, vol. 2, pp. 332-336, 2011.

[42] S. Boxiong, W. Chunfei, L. Cai, G. Binbin, and W. Rui, "Pyrolysis of waste tyres: the influence of USY catalyst/tyre ratio on products," Journal of Analytical and Applied Pyrolysis, vol. 78, no. 2, pp. 243-249, 2007.

[43] Y. Zhang, C. Wu, M. A. Nahil, and P. Williams, "Pyrolysiscatalytic reforming/gasification of waste tires for production of carbon nanotubes and hydrogen," Energy and Fuels, vol. 29, no. 5, pp. 3328-3334, 2015.

[44] L. A. Dombrovsky, S. S. Sazhin, E. M. Sazhina et al., "Heating and evaporation of semitransparent diesel fuel droplets in the presence of thermal radiation," Fuel, vol. 80, no. 11, pp. 1535-1544, 2001.

[45] J. G. Brammer and A. V. Bridgwater, "Drying technologies for an integrated gasification bio-energy plant," Renewable and Sustainable Energy Reviews, vol. 3, no. 4, pp. 243-289, 1999.

[46] M. F. Laresgoiti, B. M. Caballero, I. de Marco, A. Torres, M. A. Cabrero, and M. J. Chomón, "Characterisation of the liquid products obtained in tyre pyrolysis," Journal of Analytical and Applied Pyrolysis, vol. 71, no. 2, pp. 917-934, 2004.

[47] P. T. Williams, S. Besler, and D. T. Taylor, "The pyrolysis of scrap automotive tyres," Fuel, vol. 69, no. 12, pp. 1474-1482, 1990.

[48] G. Lopez, J. Alvarez, M. Amutio et al., "Waste truck-tyre processing by flash pyrolysis in a conical spouted bed reactor," Energy Conversion and Management, vol. 142, pp. 523-532, 2017.

[49] G. Li, B. Shen, and F. Lu, "The mechanism of sulfur component in pyrolyzed char from waste tire on the elemental mercury removal," Chemical Engineering Journal, vol. 273, pp. 446-454, 2015.

[50] F. Chen and J. Qian, "Studies on the thermal degradation of cis-1,4-polyisoprene," Fuel, vol. 81, no. 16, pp. 2071-2077, 2002.

[51] S.-S. Choi, "Characterization of bound rubber of filled styrene-butadiene rubber compounds using pyrolysis-gas chromatography," Journal of Analytical and Applied Pyrolysis, vol. 55, no. 2, pp. 161-170, 2000.

[52] J. Dodds, W. F. Domenico, D. R. Evans, L. W. Fish, P. L. Lassahn, and W. J. Toth, Scrap Tyres: A Resource and Technology Evaluation of Tyre Pyrolysis and Other Selected Alternate Technologies (No. EGG-2241), EG nd G Idaho Inc., Idaho Falls, ID, USA, 1983.

[53] R. Cypres and B. Bettens, "Production of benzoles and active carbon from waste rubber and plastic materials by means of pyrolysis with simultaneous post-cracking," in Pyrolysis Gasification, pp. 209-229, Elsevier, New York, NY, USA, 1989.

[54] E. Kwon and M. J. Castaldi, "Fundamental understanding of the thermal degradation mechanisms of waste tires and their air pollutant generation in a $\mathrm{N}_{2}$ atmosphere," Environmental Science \& Technology, vol. 43, no. 15, pp. 5996-6002, 2009.

[55] X. Meng, Z. Wang, R. Zhang et al., "Catalytic conversion of $\mathrm{C}_{4}$ fraction for the production of light olefins and aromatics," Fuel Processing Technology, vol. 116, pp. 217-221, 2013.

[56] Q. Lin, G. Chen, and Y. Liu, "Scale-up of microwave heating process for the production of bio-oil from sewage sludge,"
Journal of Analytical and Applied Pyrolysis, vol. 94, pp. 114119, 2012.

[57] G. Lopez, R. Aguado, M. Olazar, M. Arabiourrutia, and J. Bilbao, "Kinetics of scrap tyre pyrolysis under vacuum conditions," Waste Management, vol. 29, no. 10, pp. 26492655, 2009. 


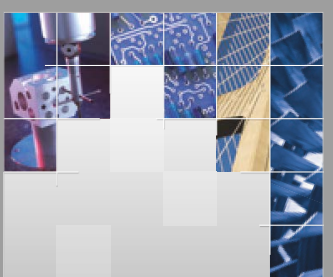

\section{Enfincering}
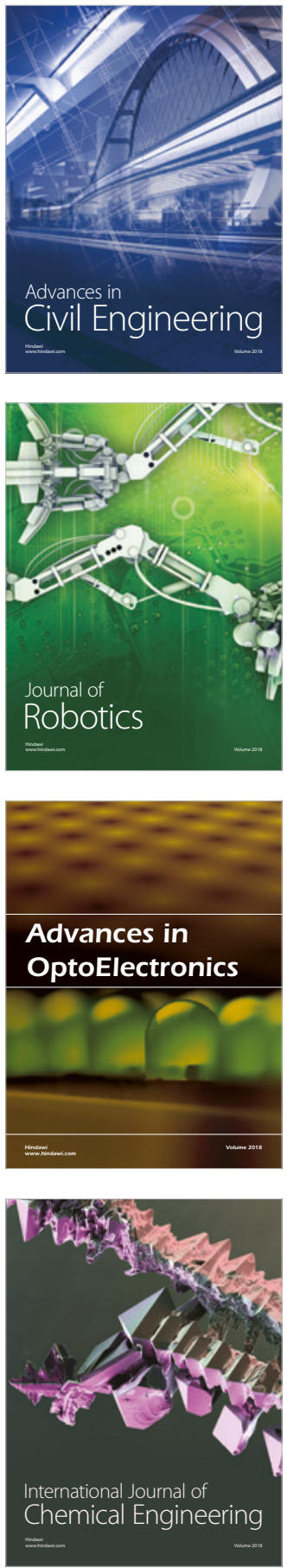

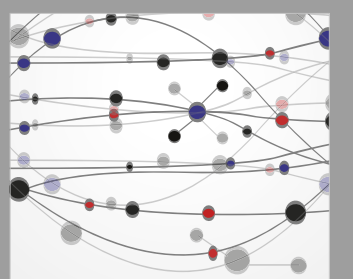

\section{Rotating \\ Machinery}

The Scientific World Journal

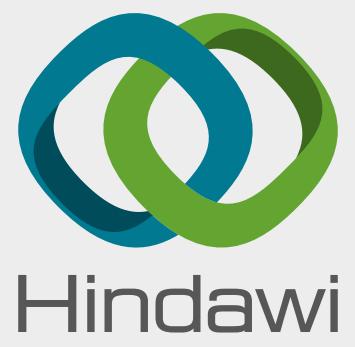

Submit your manuscripts at

www.hindawi.com
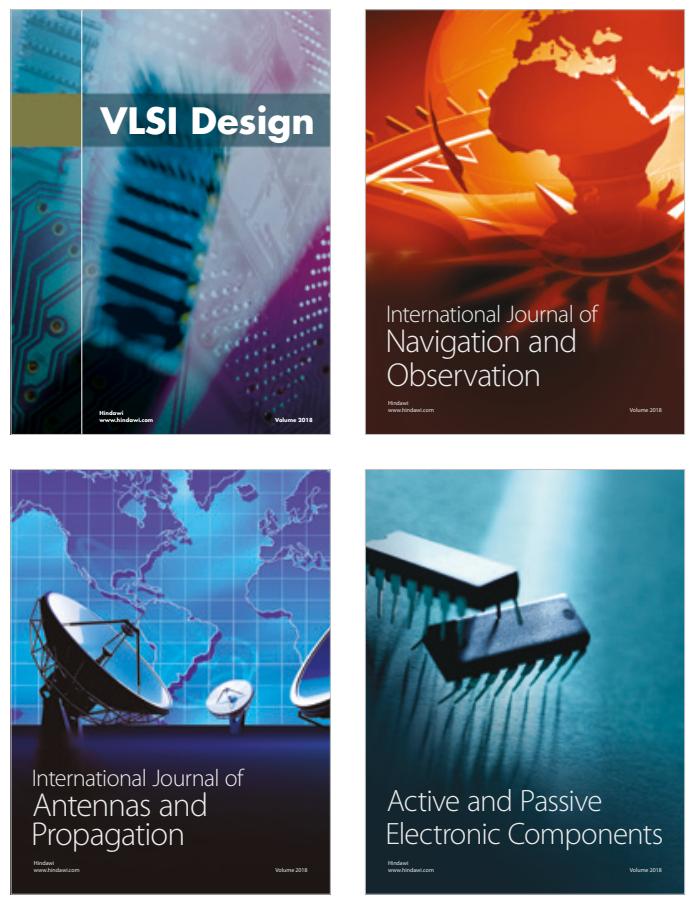
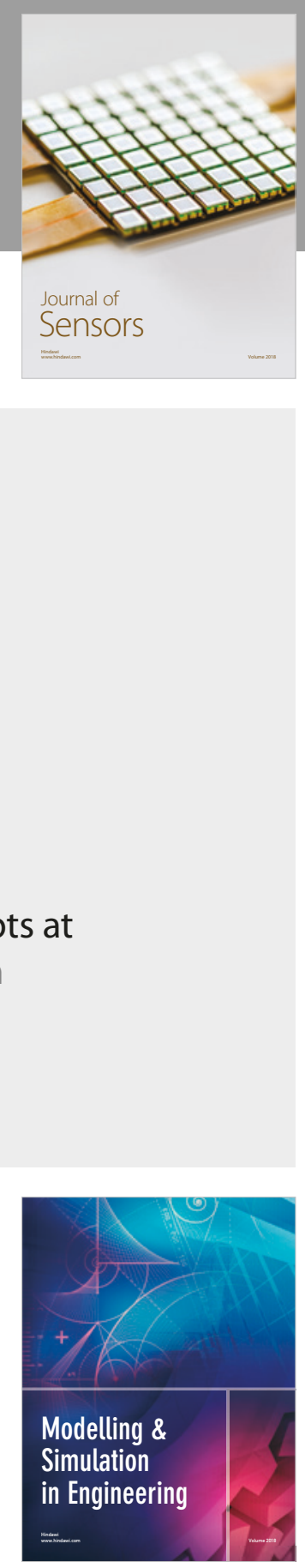

\section{Advances \\ Multimedia}
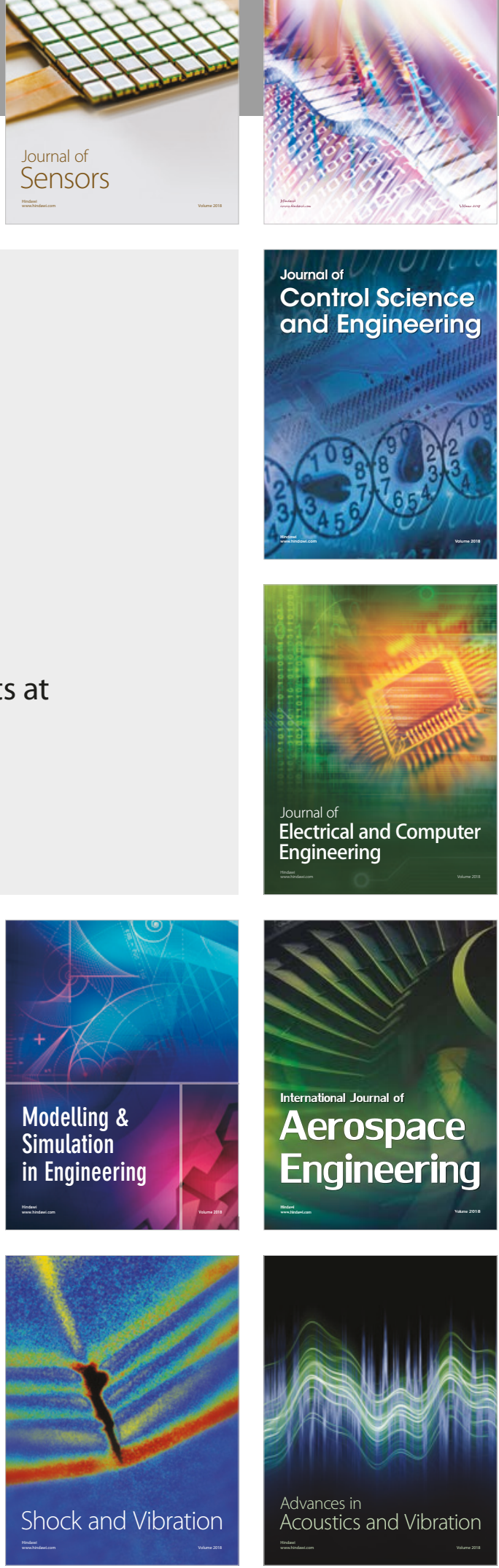